\title{
PENINGKATAN HASIL BELAJAR MATA PELAJARAN PEKERJAAN DASAR OTOMOTIF (PDO) KELAS X DENGAN METODE STUDENT TEAMS ACHIEVEMENT DIVISION (STAD) di SMK N 3 YOGYAKARTA
}

\author{
Sujiyanto \\ SMKN 3 Yogyakarta \\ Email: suji_prima@yahoo.co.id
}

\begin{abstract}
ABSTRAK
Penelitian bertujuan untuk meningkatan keaktifan dan hasil belajar mata pelajaran Pekerjaan Dasar Otomotif dengan pembelajaran kooperatif tipe STAD (Student Teams Achievement Division) di kelas X Teknik Kendaraan Ringan (TKR). Penelitian ini merupakan penelitian tindakan kelas (PTK) dan model pembelajaran yang dilakukan adalah kooperatif STAD, yang dilakukan dengan 3 siklus. Subyek penelitian adalah Peserta didik kelas X TKR 3 SMK Negeri 3 Yogyakarta yang berjumlah 31 peserta didik. Pengumpulan data dilakukan dengan observasi dan tes yang dilakukan diawal dan akhir pembelajaran. Hasil penelitian ini menunjukkan bahwa proses pembelajaran dengan metode kooperatif tipe STAD dapat meningkatkan keaktifan dan hasil belajar Peserta didik. Persentase keaktifan peserta didik mencapai kategori baik dan sangat baik $\geq 70 \%$. Sedangkan hasil belajar peserta didik telah memperoleh nilai kategori baik dan sangat baik $\geq 80 \%$.
\end{abstract}

Kata Kunci: STAD, Keaktifan, Hasil Belajar

IMPLEMENTING STUDENT TEAMS ACHIEVEMENT DIVISION (STAD) TO

IMPROVE STUDENTS' LEARNING ACHIEVEMENT ON THE BASIC AUTOMOTIVE

COURSE: AN ACTION RESEARCH STUDY AT SMK NEGERI 3 YOGYAKARTA

\begin{abstract}
This study aimed to improve students' participation and learning achievement using Students Team Achievement Division (STAD) on the Basic Automotive course. This classroom action research was performed consisting of three cycles. Each cycle consisted of planning, action, observation, and reflection. There were 31 students from SMK Negeri 3 Yogyakarta selected as participants for the study. Data were collected using observation sheet and test at the beginning and end of classroom activities. The results of this study indicated that implementing STAD method can improve students' learning outcomes. There were seventy percent or more $(\geq 70 \%)$ students actively participated in the classroom activities. Furthermore, there were eighty percent or more $(\geq 80 \%)$ students reached higher score than the minimum requirement for their test.
\end{abstract}

Key Words: STAD, Students' participation, Student's achievement 


\section{PENDAHULUAN}

Kegiatan belajar diperlukan keterlibatan unsur fisik maupun mental, sebagai suatu wujud reaksi. Belajar harus aktif, tidak sekedar apa adanya, menyerah pada lingkungan, tetapi semua itu harus dipandang sebagai tantangan yang memerlukan reaksi. Jadi orang yang belajar itu harus aktif, bertindak dan melakukannya dengan segala panca indranya secara optimal. Dalam proses pembelajaran seorang guru diharapkan tidak hanya mampu memberikan pengetahuan dengan penyampaian informasi saja, namun harus dapat melibatkan peserta didik secara aktif membangun pengetahuan dalam pikiran mereka sendiri. Selain itu guru juga harus memberikan dukungan dan kesempatan pada peserta didik untuk mengembangkan ide-idenya. Pikiran dan otot-ototnya harus dapat bekerja secara harmonis, sehingga subjek belajar itu bertindak atau melakukannya. Belajar membutuhkan reaksi yang melibatkan ketangkasan, kewaspadaan, perhitungan, ketekunan dan kecermatan untuk menangkap fakta-fakta dan ideide sebagaimana disampaikan oleh pengajarnya. Guna membenahi sistem pembelajaran yang lebih bermakna, maka kegiatan belajar itu sendiri harus dirancang sedemikian rupa, sehingga seluruh peserta didik menjadi aktif dalam belajarnya, yang dapat merangsang daya cipta, rasa maupun karsa. Cara belajar yang aktif diasumsikan menjadi pangkal kesuksesan belajar (Muhadjir, 2003:137). Bertolak dari asumsi tersebut, maka metode dan teknik belajar mengajar harus ditelaah untuk dapat mengaktifkan peserta didik sebagai subyek didik.

Mata pelajaran disusun menurut tingkat dan kompetensi yang harus dicapai. Hal ini sesuai dengan Permendikbud No. 70 tahun 2013 mengenai kerangka dasar dan struktur kurikulum terdiri dari kompetensi inti dan kompetensi mata pelajaran. Kompetensi inti dirancang seiring dengan meningkatnya usia peserta didik pada kelas tertentu, kompetensi mata pelajaran untuk pendidikan menengah kejuruan kelompok teknologi dan rekayasa, khususnya teknik kendaraan ringan terdiri dari kelompok A dan B terdiri dari kelompok mata pelajaran normatif adaptif. Kelompok C1 kejuruan dasar bidang keahlian, C2 dasar program keahlian dan C3 paket keahlian. Dasar program keahlian terdiri Teknologi Dasar Otomotif, Pekerjaan Dasar Otomotif, Teknik Listrik Dasar Otomotif, Simulasi Digital. Pekerjaan Dasar Teknik Otomotif memiliki 4 kompetensi inti, Kompetensi Inti dirancang dalam empat kelompok yang saling terkait yaitu berkenaan dengan sikap keagamaan (kompetensi inti 1), sikap sosial (kompetensi 2), pengetahuan (kompetensi inti 3), dan penerapan pengetahuan (kompetensi 4). Keempat kelompok itu menjadi acuan dari Kompetensi Dasar dan harus dikembangkan dalam setiap peristiwa pembelajaran secara integratif. Kompetensi yang berkenaan dengan sikap keagamaan dan sosial dikembangkan secara tidak langsung (indirect teaching) yaitu pada 
waktu peserta didik belajar tentang pengetahuan (kompetensi kelompok 3) dan penerapan pengetahuan (kompetensi Inti kelompok 4). Pada kompetensi 3 dan 4 memiliki 11 kompetensi dasar, diantaranya: Mengidentifikasi jenis-jenis alat ukur mekanik dan fungsinya, dan Menggunakan alat-alat ukur mekanik sesuai operation manual.

Berdasarkan perolehan nilai rata-rata hasil ujian Tengah Semester pelajaran PDO di kelas X TKR 3 SMKN 3 Yogyakarta masih dibawah nilai KKM yang ditentukan yaitu 75. Disamping itu berdasarkan hasil penilaian akhir semester (PAS) gasal tahun pelajaran 20182019 nilai mata pelajaran PDO diperoleh nilai rata-rata 62, nilai tertinggi 80 dan nilai terendah 33. Ini merupakan gejala permukaan atau ada indikasi bahwa penguasaan materi yang diserap peserta didik masih rendah. Banyak faktor yang mempengaruhi prestasi belajar peserta didik, contoh, sebagian besar sekolah termasuk di kelas SMKN 3 Yogyakarta masih banyak guru menggunakan pembelajaran konvensional (ceramah). Dalam pembelajaran metode konvesional guru ditempatkan sebagai pusat kegiatan dan sebagai sumber ilmu sehingga guru memegang peranan penting dan berkuasa penuh dalam kegiatan belajar mengajar.

Mata pelajaran Pekerjaan Dasar Otomotif merupakan mata pelajaran produktif yang harus diikuti oleh peserta didik teknik otomotif di SMKN 3 Yogyakarta. Salah satu upaya untuk mengatasi kendala di atas, khususnya pada mata pelajaran Pekerjaan Dasar Otomotif adalah dengan memanfaatkan metode pembelajaran sebagai suatu cara dalam penyampaian materi mata pelajaran. Metode pembelajaran juga dapat meningkatkan kualitas pembelajaran karena dapat mempermudah guru dalam penyampaian materi serta meningkatkan keaktifan peserta didik dalam menagggapi pelajaran yang diselenggarakan sehingga dapat meningkatkan keaktifan dan hasil belajar peserta didik .

Metode pengajaran yang selama ini digunakan pada mata pelajaran Pekerjaan Dasar Teknik Otomotif ini tidak efektif sehingga hasil akhir yang diperoleh kurang maksimal. Menyadari begitu pentingnya penguasaan terhadap konsep dasar pengukuran benda kerja secara tepat dan presisi perlu diterapkan metode pembelajaran untuk meningkatkan penguasaan materi yang akan meningkatkan pengetahuan Pekerjaan Dasar Otomotif Dalam penelitian ini peneliti menerapkan metode pembelajaran dengan mengoptimalkan partisipasi peserta didik dalam proses pembelajaran yang efektif dan dapat memberikan pengalaman kongkret kepada peserta didik dan mempermudah peserta didik dalam menerima pelajaran atau informasi serta dapat menghindarkan salah pengertian. Penelitian dengan penerapan metode pembelajaran Student Teams Achievement Division (STAD) sangat penting dan mendesak dilakukan dalam upaya meningkatkan pengetahuan Pekerjaan Dasar Otomotif 
Berdasarkan identifikasi masalah tersebut selanjutnya masalah dibatasi pada metode pembelajaran Student Teams Achievement Division (STAD) sebagai upaya untuk meningkatkan keaktifan dan hasil belajar mata pelajaran Pekerjaan Dasar Otomotif peserta didik kelas X TKR 3 di SMKN 3 Yogyakarta. Oleh karena itu, penelitian ini bertujuan untuk meningkatan keaktifan belajar dan hasil belajar peserta didik dalam mata pelajaran pekerjaan dasar otomotif melalui penerapan metode pembelajaran metode STAD di kelas X TKR 3 SMKN 3 Yogyakarta.

\section{KAJIAN PUSTAKA}

\section{Keaktifan dan hasil belajar}

Keaktifan belajar merupakan unsur dasar yang penting bagi keberhasilan proses pembelajaran. Belajar merupakan tindakan dan perilaku peserta didik yang komplek. Sebagai tindakan, maka belajar hanya dialami oleh peserta didik sendiri. Peserta didik adalah penentu terjadinya atau tidak terjadinya proses belajar (Dimyati, 2008:7). Peserta didik yang memiliki aktifitas mental adalah jika daya jiwanya bekerja sebanyak-banyaknya atau banyak berfungsi dalam rangka pembelajaran. Belajar yang berhasil harus melalui berbagai macam aktifitas, baik aktifitas fisik maupun mental. Aktivitas fisik adalah peserta didik giat aktif dengan anggota badan, membuat sesuatu bermain maupun bekerja, peserta didik tidak hanya duduk mendengarkan, melihat atau hanya pasif. Keaktifan siswa dalam proses pembelajaran diharapkan dapat menghasilkan prestasi belajar yang optimal. Hasil Belajar merupakan kapabilitas atau kemampuan Peserta didik berupa: informasi verbal, ketrampilan intelektual, strategi kognitif, ketrampilan motorik, sikap (Dimyati, 2008).

Mata Pelajaran Pekerjaan Dasar Teknik Otomotif (PDTO) Berdasarkan Permendikbud No. 70 tahun 2013 terdiri dari Teknologi Dasar Otomotif. Pekerjaan Dasar Otomotif (PDO) dalam penelitian ini adalah Pembelajaran alat ukur yang merupakan salah satu kompetensi dasar yang dipelajari di SMK Negeri 3 Yogyakarta.

\section{Student Teams Achievement Division (STAD)}

Gagasan utama dari STAD adalah untuk memotivasi peserta didik supaya dapat saling mendukung dan membantu satu sama lain dalam menguasai kemampuan yang diajarkan oleh guru (Slavin, 2010:12). STAD merupakan salah satu metode pembelajaran kooperatif yang paling sederhana dan merupakan model yang paling baik untuk permulaan bagi para guru yang menggunakan pendekatan kooperatif (Slavin, 2010:143). Pelaksanaan STAD terdiri dari lima komponen utama pembelajaran kooperatif yaitu: (a) Presentasi kelas. (b) Tim/belajar kelompok, (c) Kuis, (d) Skor kemajuan individual, (e) rekognisi/penghargan tim. 


\section{METODE PENELITIAN}

Penelitian ini merupakan Penelitian Tindakan Kelas (PTK) atau Classroom Action Research $(C A R)$ yang dilakukan oleh peneliti sebagai guru mata pelajaran pekerjaan dasar otomotif dengan guru pendamping yang berfungsi sebagai observer dan partner dalam proses pembelajaran mata pelajaran pekerjaan dasar otomotif pada peserta didik kelas X TKR 3 SMKN 3 Yogyakarta. Menurut Afandi (2011: 9) penelitian tindakan kelas dapat dijelaskan sebagai berikut:

1. Penelitian adalah kegiatan ilmiah dengan menggunakan metode yang berdasarkan fakta untuk menemukan untuk menemukan, mengembangkan dan mengevaluasi suatu pengetahuan, dalam hal ini dapat meningkatkan mutu pembelajaran.

2. Tindakan adalah gerakan yang dilakukan dengan sengaja dilakukan dengan tujuan tertentu yang dalam penelitan terbentuk rangkaian langkah-langkah (siklus) yang terdiri dari perencanaan, tindakan, observasi, dan refleksi yang terus mengalir menghasilkan siklus baru sampai penelitan tindakan kelas dihentikan.

3. Kelas adalah tempat di mana terdapat sekelompok peserta didik yang dalam waktu bersamaan menerima pelajaran dari guru yang sama.

Penelitian tindakan kelas ini menggunakan model Action Research Spiral yang dikembangkan oleh Kemmis dan Taggart, yang terdiri dari empat tahapan, yaitu : 1) Perencanaan (Plan), 2) Tindakan (Action), 3)Pengamatan (Observation), 4) Refleksi (Reflection). Subjek Penelitian adalah Peserta didik kelas X TKR 3 SMK Negeri 3 Yogyakarta tahun pelajaran 2018/2019.

Teknik Pengumpulan Data Pengumpulan Data diperoleh melalui observasi, tes, dokumentasi dan catatan lapangan. Sedangkan Teknik Analisis Data data untuk keaktifan belajar adalah persentase keaktifan Peserta didik yang disampaikan dalam bentuk deskriptifa. Selanjutnya untuk hasil belajar dianalisis berdasarkan nilai rata-rata dan persentase nilai ratarata.

Sesuai dengan karakteristik penelitian tindakan kelas, keberhasilan penelitian ditandai dengan adanya perubahan kearah perbaikan, baik yang terkait dalam pelaksanaan proses pembelajaran maupun hasil pembelajaran. Sebagai kriteria keberhasilan-keberhasilan yang dicapai peserta didik di dalam penelitian ini adalah:

a. Peserta didik mempunyai keaktifan yang tinggi dalam mengikuti pembelajaran selalu memperhatikan selama proses pembelajaran sedang berlangsung. Selalu merespon setiap pertanyaan yang diberikan oleh guru, aktif dalam diskusi atau kelompok belajarnya dan 
aktif dalam mengerjakan soal atau tugas. Persentase keaktifan peserta didik mencapai kategori baik atau sangat baik $\geq 70 \%$ dari jumlah peserta.

b. Kelas dikatakan berhasil dalam belajar apabila $80 \%$ peserta didik telah memperoleh nilai kategori baik dan sangat baik atau $\geq 80$ dengan nilai maksimal 100 yang ditetapkan oleh sekolah yang bersangkutan dan nilai rata-rata kelas mengalami peningkatan.

\section{HASIL PENELITIAN DAN PEMBAHASAN}

Setelah dilakukan evaluasi terhadap tindakan kelas selama tiga siklus dapat dilaporkan segi-segi hasil penelitian yang dapat mencapai tujuan yang diinginkan serta segi-segi lain yang dianggap kurang memenuhi harapan dan masih memerlukan perhatian dan tindak lanjut yang lebih mendalam.

Penggunaan metode kooperatif tipe STAD dalam pembelajaran telah dapat membantu Peserta didik dalam menggali pengetahuannya dan mengaktifkan Peserta didik. Pembelajaran ini tidak monoton dan tidak lagi berpusat pada guru melainkan pada Peserta didik, dimana Peserta didik berusaha menemukan, menggali pengetahuannya sendiri melalui kelompok diskusi masing-masing. Dengan pembelajaran kooperatif tipe STAD yang berpusat pada Peserta didik menyebabkan Peserta didik ikut merasa memiliki kegiatan pembelajaran tersebut, karena Peserta didik diikutsertakan secara aktif dalam pelaksanaan pembelajaran sehingga mendorong peningkatan keaktifan belajar, motivasi belajar, disiplin, tanggung jawab dan mempunyai inisiatif sendiri sehingga dapat menyebabkan meningkatnya prestasi belajar Peserta didik .

Penggunaan soal diskusi dalam pembelajaran kelompok dapat meningkatkan interaksi antara Peserta didik dengan peneliti maupun antara sesame Peserta didik, baik dengan anggota dalam kelompoknya atau dengan anggota kelompok lain. Peserta didik saling bekerjasama dalam mengerjakan soal diskusi. Selain itu Peserta didik juga menjadi aktif dan berani mengemukakan pendapat dan gagasannya serta memiliki pemikiran yang maju di dalam kelompoknya.

Sama halnya dengan penelitian ini bahwa metode kooperatif tipe STAD dalam pembelajaran penggunaan alat ukur juga dapat meningkatkan keaktifan belajar Peserta didik. Hal pertama yang dilakukan peneliti guna meningkatkan keaktifan belajar Peserta didik adalah mengaktifkan Peserta didik dalam kegiatan pembelajaran dan belajar kelompok atau kelompok diskusi. Cara ini dapat membuat Peserta didik yang awalnya kesulitan dalam mengerjakan soal menjadi lebih mudah ketika dikerjakan secara kelompok. Kegiatan belajar aktif telah membuat 
Peserta didik semakin antusias dalam mengikuti pelajaran dan Peserta didik tidak jenuh dengan proses belajar mengajar yang berlangsung.

Dalam proses belajar mengajar peneliti tidak lagi berperan sebagai pusat mengajar melainkan berperan sebagai fasilitator, mediator dan pembimbing kegiatan pembelajaran yang membantu agar proses belajar Peserta didik berjalan dengan baik. Peneliti menyediakan kegiatan-kegiatan yang merangsang keingintahuan Peserta didik serta membantu mengungkapkan idenya secara ilmiah yang memungkinkan Peserta didik bertanggung jawab dalam belajar.

Hasil belajar mata pelajaran penggunaan alat ukur pada pokok bahasan alat ukur mekanis presisi yang meliputi jangka sorong, micrometer luar dan dial indikator mengalami peningkatan, peningkatan dapat dilihat dari kenaikan nilai rata-rata pada setiap siklusnya dan persentase perolehan nilai kategori baik dan sangat baik pada setiap siklusnya. Menunjukan untuk pra siklus kenaikan nilai rata-rata dari pre-test ke post-test sebesar 4,52\%, untuk siklus I kenaikan nilai rata-rata sebesar 3\%, untuk siklus II kenaikan nilai rata-rata sebesar $14,77 \%$ dan untuk siklus III kenaikan nilai rata-rata sebesar $12 \%$. Sedangkan untuk kategori nilai baik dan sangat baik pada pra tindakan terdapat 5 peserta didik (16\%), pada akhir siklus I terdapat 18 peserta didik (58\%), pada akhir siklus II terdapat 25 peserta didik $(81 \%)$ dan pada akhir siklus III terdapat 27 peserta didik ( $87 \%$ ). Berikut disajikan grafik peningkatannya.

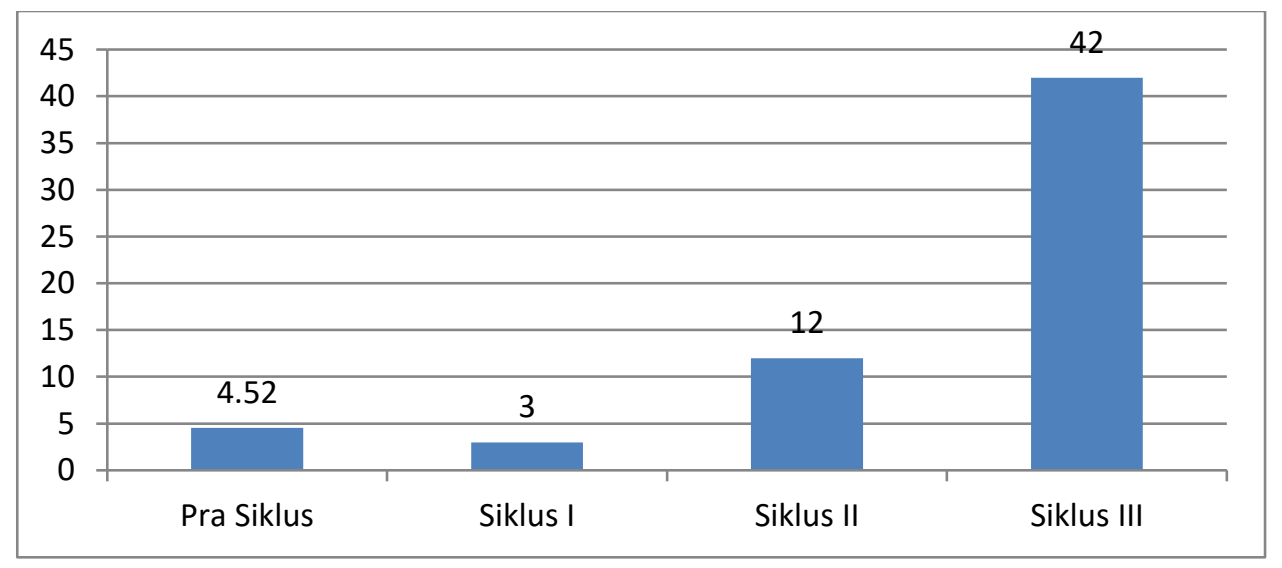

Gambar 1. Grafik Kenaikan Nilai Rata-rata pada tiap siklus

Bersadarkan grafik diatas ditunjukan pada pra siklus dicapai kenaikan nilai rata-rata 4,52\%, pada siklus I sebesar 3\%, pada Siklus II sebesar $12 \%$ dan untuk siklis III sebesar 42 $\%$, dari data tersebut menunjukan pada pra siklus 


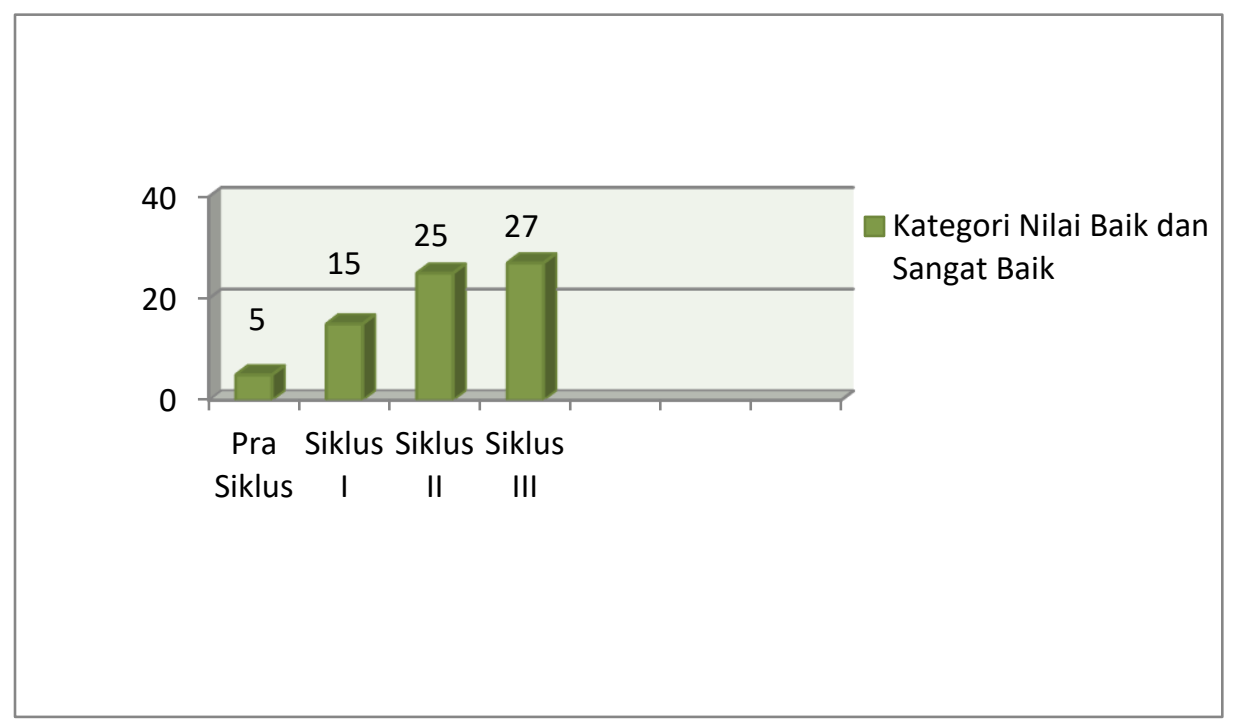

Gambar 2. Grafik Kategori Nilai Baik dan Sangat Baik pada akhir Pra Siklus, SiklusI, Siklus II dan akhir Siklus III

Keaktifan belajar mata pelajaran penggunaan alat ukur pada pokok bahasan alat ukur mekanis presisi yang meliputi jangka sorong, micrometer luar dan dial indikator mengalami peningkatan yang dapat dilihat dari pengamatan selama proses tindakan perolehan persentase keaktifan belajar kategori baik dan sangat baik pada akhir pra tindakan tidak terdapat peserta didik (0\%), pada akhir siklus I terdapat 18 peserta didik $(58,06 \%)$, pada akhir siklus II terdapat 20 peserta didik $(64,52 \%)$ dan pada akhir siklus III terdapat 27 peserta didik (87,10\%). Berikut disajikan diagaram kategori keaktifan belajar peserta didik dari siklus I, siklus II dan siklus III, dengan grafik sebagai berikut:

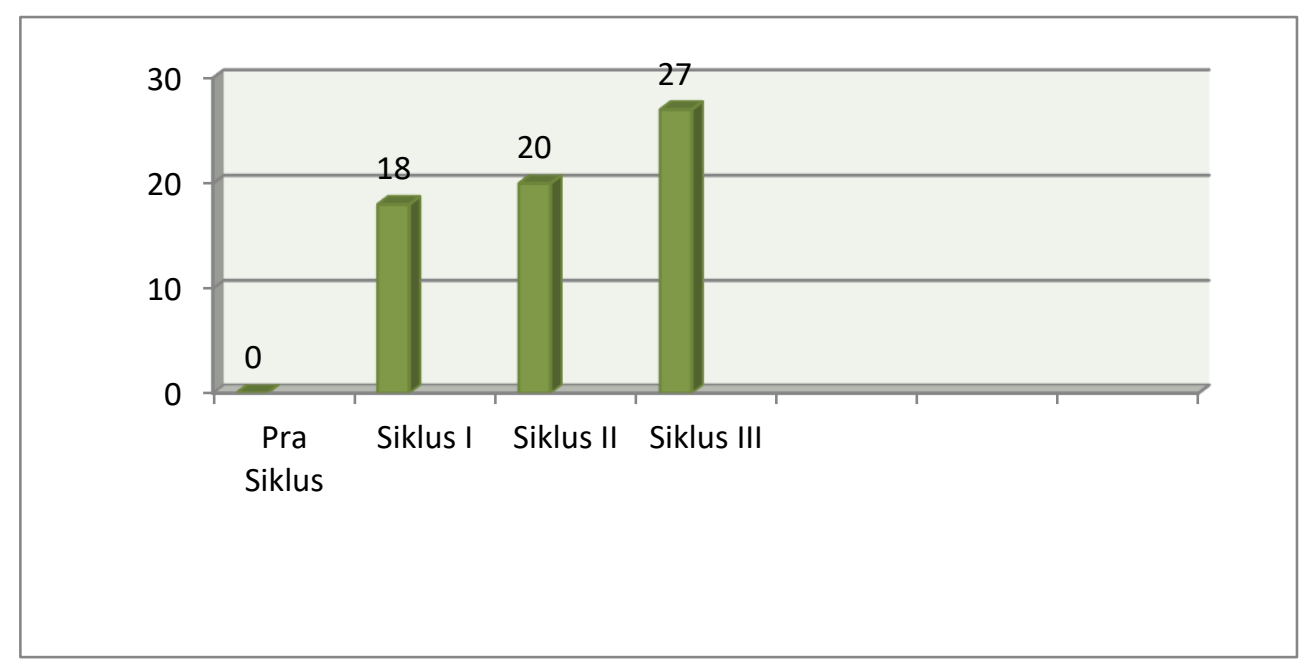

Gambar 3. Grafik Hasil Observasi Keaktifan Belajar Peserta didik 
Semua data yang telah dideskripsikan diatas merupakan hasil dari implikasi tindakan yang telah dilaksanakan. Hasil belajar peserta didik pada mata pelajaran penggunaan alat ukur telah mencapai kategori nilai baik dan sangat baik untuk klasikal $\geq 70 \%$ dari jumlah peserta akhir pada siklus II dan pada akhir siklus III, dengan keberhasilan telah tercapai pada siklus II sebesar 80,65 \% tetapi dilanjutkan pada siklus III untuk mendapatkan kenaikan persentase nilai baik dan sangat baik yang lebih baik dengan keberhasilan atau persentase mencapai $87,10 \%$ pada siklus III. Untuk keaktifan belajar peserta didik pada mata pelajaran penggunaan alat ukur telah mencapai kategori keaktifan baik dan sangat baik untuk klasikal $\geq$ $70 \%$ dari jumlah peserta pada siklus II dan pada akhir siklus III, dengan keberhasilan telah tercapai pada siklus II sebesar 64,52 \% tetapi dilanjutkan pada siklus III untuk mendapatkan kenaikan persentase keaktifan kategori baik dan sangat baik yang lebih baik dengan keberhasilan atau persentase mencapai $87,10 \%$ pada siklus III.

\section{KESIMPULAN DAN SARAN}

Penerapan model kooperatif tipe STAD dapat meningkatkan keaktifan Peserta didik dari 58,06\% menjadi 87,10\% pada mata pelajaran pekerjaan dasar otomotif kelas X TKR 3 di SMKN 3 Yogyakarta. Selain itu, metode kooperatif tipe STAD juga dapat membantu hasil belajar Peserta didik meningkat mencapai nilai KKM dari 51,61\% menjadi 87,10\% pada mata pelajaran pekerjaan dasar otomotif kelas X TKR 3 di SMKN 3 Yogyakarta.

Berdasarkan hasil penelitian yang telah dilaksanakan, maka dapat disarankan untuk memberikan tugas yang bervariasi kepada peserta didik supaya tidak bosan dan tetap bersemangat mengikuti pembelajaran. Selain itu, pembelajaran dengan kooperatif tipe STAD dapat berjalan efektif atau dapat mencapai sasaran, apabila guru memiliki keterampilan membimbing belajar kelompok, Peserta didik mengikuti perintah guru dengan baik dan menujukkan kemandirian belajar. Oleh karena itu disarankan untuk memberikan bekal ketrampilan kepada guru untuk meningkatkan kemampuannya dalam membimbing belajar kelompok dan memotivasi siswa untuk belajar lebih aktif.

\section{DAFTAR PUSTAKA}

Dimyati. 2008. Belajar dan Pembelajaran, Jakarta: PT. RinekaCipta

Muhadjir, Neong. 2003. Ilmu Pendidikan \& Perubahan Sosial. Teori Pendidikan Perilaku Sosial Kreatif. Yogyakarta: Rake Sarasin 
94 Sujiyanto

Muhammad Afandi. 2011. Cara Efektif Menulis Karya Ilmiah seting Penelitian Tindakan Kelas. Bandung: Alfabeta

Permendikbud Nomor 70 tahun 2013, tentang Kerangka Dasar dan struktur Kurikulum, Pendidikan dan Kebudayaan RI. Jakarta

Sasongko. 2013. Pekerjaan Dasar Teknik Otomotif. Kementrian . Pendidikan dan Kebudayaan RI. Jakarta

Sardiman, A.M. 2001. Interaksi dan keaktifan belajar mengajar. Jakarta, PT. Rajagrafindo Persada.

Robert E Slavin. 2005. Cooperatif Learning: Theory, Research, And Practice (Terjemahan Narulita Yusron). London: Allymand Bacon 